\title{
Clinical Features of Fatal Pandemic Influenza A/H1N1 Infection Complicated by Invasive Pulmonary Fungal Infection
}

\author{
Zhuxi Yu $\cdot$ Qin Gu $\cdot$ Beiyuan Zhang $\cdot$ Xiancheng Chen $\cdot$ Jian Tang $\cdot$ \\ Yayi Hou - Wenkui Yu
}

Received: 11 September 2018/Accepted: 16 December 2019/Published online: 27 December 2019

(C) The Author(s) 2019

\begin{abstract}
Background Severe pneumonia caused by influenza virus infection can be secondary to invasive pulmonary fungal (IPF) infection.

Objectives This study aimed to summarize the incidence of IPF infection secondary to influenza virus infection and further explore its etiologic mechanism and high-risk factors.

Methods All adult patients with confirmed influenza A (H1N1) virus infection admitted to the intensive care units (ICUs) of Nanjing Drum Hospital from November 2017 to March 2018 were retrospectively selected. The differences in baseline factors, risk factors, immune function and outcome parameters were studied between patients with and without IPF. Results Of the 19 critically ill patients with H1N1 infection, 11 (57.9\%) developed IPF infection after 7 days of ICU admission. Two patients had proven and nine probable IPF infection. A difference in human leukocyte antigen-DR isotype ( $\triangle \mathrm{HLA}-\mathrm{DR}$; day 7-day 1) was found between the two groups. $\triangle$ HLA-DR (day 7-day 1) was higher in patients with no IPF infection than in those with IPF infection
\end{abstract}

Handling Editor: Weida Liu.

Z. Yu - Q. Gu - B. Zhang · X. Chen · J. Tang .

Y. Hou $\cdot$ W. Yu ( $₫)$

Nanjing University Medical School Affiliated Nanjing

Drum Tower Hospital, Nanjing, China

e-mail: yudrnj@163.com
$[(14.52 \pm 14.21) \% \quad$ vs $\quad(-11.74 \pm 20.22) \%$, $P=0.019]$. The decline in HLA-DR indicated impaired immune function secondary to fungal infection in patients with $\mathrm{H} 1 \mathrm{~N} 1$ infection.

Conclusions IPF infection was diagnosed in 57.9\% of critically ill patients with $\mathrm{H} 1 \mathrm{~N} 1$ virus infection after a median of 7 days following ICU admission. A continuous decline in immune function could lead to the development of IPF infections. Dynamic monitoring of immune function may help in the early detection of IPF infection.

Keywords H1N1 - Human leukocyte antigen-DR isotype (HLA-DR) · Invasive pulmonary fungal infection $\cdot$ Severe pneumonia

$\begin{array}{ll}\begin{array}{l}\text { Abbreviations } \\ \text { APACHE II }\end{array} & \begin{array}{l}\text { Acute physiology and chronic } \\ \text { evaluation II score }\end{array} \\ \text { ARDS } & \text { Acute respiratory distress syndrome } \\ \text { BAL } & \text { Bronchoalveolar lavage fluid } \\ \text { CRRT } & \text { Continuous renal replacement } \\ & \text { therapy } \\ \text { ECMO } & \text { Extracorporeal membrane } \\ & \text { oxygenation } \\ \text { GM } & \text { Galactomannan } \\ \text { HFNC } & \text { High-flow nasal cannulae } \\ \text { HLA-DR } & \text { Human leukocyte antigen-DR } \\ \text { ICU } & \text { isotype } \\ & \text { Intensive care unit }\end{array}$


IPF Invasive pulmonary fungal

MODS Multiple organ dysfunction syndrome

SOFA

\section{Introduction}

Since the first case of influenza A (H1N1) virus infection found in Mexico in 2009, the virus has spread worldwide and resulted in pandemics [1]. Nearly 60.8 million were infected with H1N1from April 2009 to April 2010; of these, 274,304 were hospitalized and 12,469 died in the USA [2, 3]. The H1N1 infection was usually complicated by several diseases including acute respiratory distress syndrome, cardiac disorders, bacterial pneumonia and others. Pneumonia was one of the most common complications. Influenza and pneumonia mortality accounted for $2.2 \%$ and $2.0 \%$, becoming the eighth and ninth causes of death in 2009 and 2010 in the USA, respectively [4, 5]. Recent studies also revealed that $18-61 \%$ of hospitalized patients with $\mathrm{H} 1 \mathrm{~N} 1$ infection had pneumonia characteristics, demanding more attention to influenzainduced pneumonia [6-8].

Previous studies have shown that severe pneumonia caused by influenza virus infection can be secondary to invasive pulmonary fungal (IPF) infection. It is probably because these people have predisposing factors, such as lung disease, malignancy and chronic obstructive pulmonary disease, affecting the function of $\mathrm{T}$ lymphocytes, macrophages and neutrophils, or influenza increases susceptibility to bacterial superinfection by altering defensive mechanisms [9, 10]. Once it occurs, treatment decisions change and the prognosis is greatly different [11]. However, due to the limited case reports in recent years, the robust data on the prevalence, pathogenesis, risk factors and final prognosis of the aforementioned infection are sparse [12-14]. In a retrospective study published in 2012 , the authors recruited 40 critically ill patients with $\mathrm{H} 1 \mathrm{~N} 1$ infection and nine of them developed invasive pulmonary aspergillosis, accounting for $23 \%$ [15].

This study included 19 cases of severe pneumonia caused by influenza virus needing treatment and monitoring at the intensive care unit (ICU) in the last 4 months to provide more data for the H1N1-complicated IPF infection. In this retrospective study, the incidence of invasive fungal infection secondary to influenza virus was summarized and its etiology mechanism and high-risk factors were further explored (Fig. 1).

\section{Materials and Methods}

Study Population

This study was performed at the adult ICUs of Nanjing Drum Hospital. The medical records of all the patients with H1N1 virus infection during or 1 week prior to the ICU stay from November 2017 to March 2018 were retrospectively reviewed. The exclusion criteria were as follows: (a) age $<18$ or $\geq 80$ years; (b) had primary immunodeficiency disease, autoimmune disease or malignancy; (c) received hormones or immunosuppressive agents for nearly 3 months or surgical intervention; and (d) died within 14 days of hospitalization.

The diagnosis of H1N1 virus infection was based on a positive result in a probe-based reverse transcription polymerase chain reaction test for $\mathrm{H} 1 \mathrm{~N} 1$ from a nasopharyngeal swab or bronchoalveolar lavage (BAL) fluid. This observational retrospective study without any specific intervention was reviewed and approved by the hospital's institutional review boards. All data were processed anonymously.

\section{Definitions}

IPF infection was confirmed following the revised European Organization for Research and Treatment of Cancer/Invasive Fungal Infections Cooperative Group and the National Institute of Allergy and Infectious Diseases Mycoses Study Group (EORTC/MSG) guidelines.

The patients had proven IPF infection if the microscopic evidence of dichotomous branching hyphae with a positive culture for fungi from endobronchial biopsy (not BAL) was obtained, irrespective of host factors or clinical features (Fig. 2).

Probable IPF infection required a host factor, clinical features and mycological evidence of fungi. The mycological evidence was based on microscopy or culture of fungi from a BAL specimen or a galactomannan (GM) optical index (0.5 from a BAL 

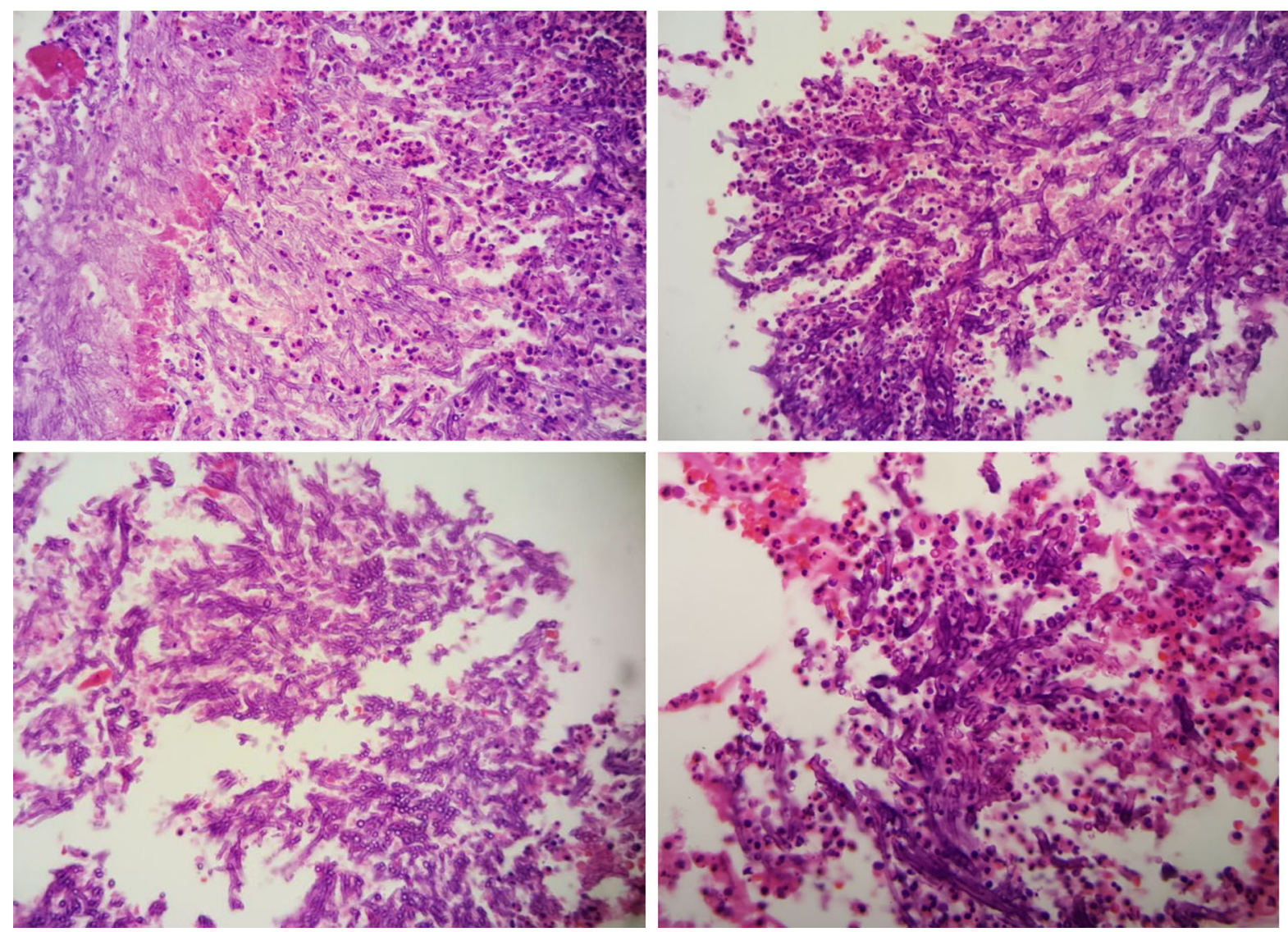

Fig. 1 Pathological examination of the airway mass from patients 6 and 7 revealed fibrous necrotic tissue and fungal filaments, which confirmed a fungal infection $(\times 100)$

or serum sample). The sandwich enzyme-linked immunosorbent assay for GM detection was performed according to the manufacturer's protocol. Lower tract respiratory samples were inoculated onto a Sabouraud agar (2 days at $37{ }^{\circ} \mathrm{C}$ and another 19 days at $30^{\circ} \mathrm{C}$ ) for fungal isolation. Fungal species were identified by their culture characteristics and morphologies.

The severity of illness was assessed using the acute physiology and chronic evaluation (APACHE) II score and the sequential organ failure assessment (SOFA) score after $24 \mathrm{~h}$ of admission.

The doses and frequency of all drugs administered in the month before and during admission to the ICU were updated in the medical records.

Biochemical data, including CD4 + /CD8 + ratio, percentage of natural killer (NK) and $\mathrm{B}$ cells and human leukocyte antigen-DR isotype (HLA-DR) in peripheral blood mononuclear cells, were recorded.
Peripheral venous blood samples $(2 \mathrm{~mL})$ were obtained from patients on days 1, 3, 5 and 7 after admission using a strict aseptic technique. Biochemical data were determined using the BD Multitest Identification Mark Kit (BD Corporation, USA, state code 340503). The other reagents and equipment used were as follows: fluorescein isothiocyanate antihuman CD14 (eBioscience Corporation, USA, state code IM1638U), phycoerythrin (PE) antihuman HLA-DR (eBioscience Corporation), PE mouse immunoglobulin $\mathrm{G}$ ( $\mathrm{IgG}) 2 \mathrm{~b}$ isotype control (eBioscience Corporation, state code IM0464U), FACSort flow cytometer (BD Corporation) and CellQuest software.

\section{Statistical Analysis}

The SPSS22.0 software was used for data analysis. The quantitative data with normal distribution and homogeneity of variance were expressed as 
Fig. 2 Time course of HLA-DR expression (\%) in the IPF and no-IPF groups after admission

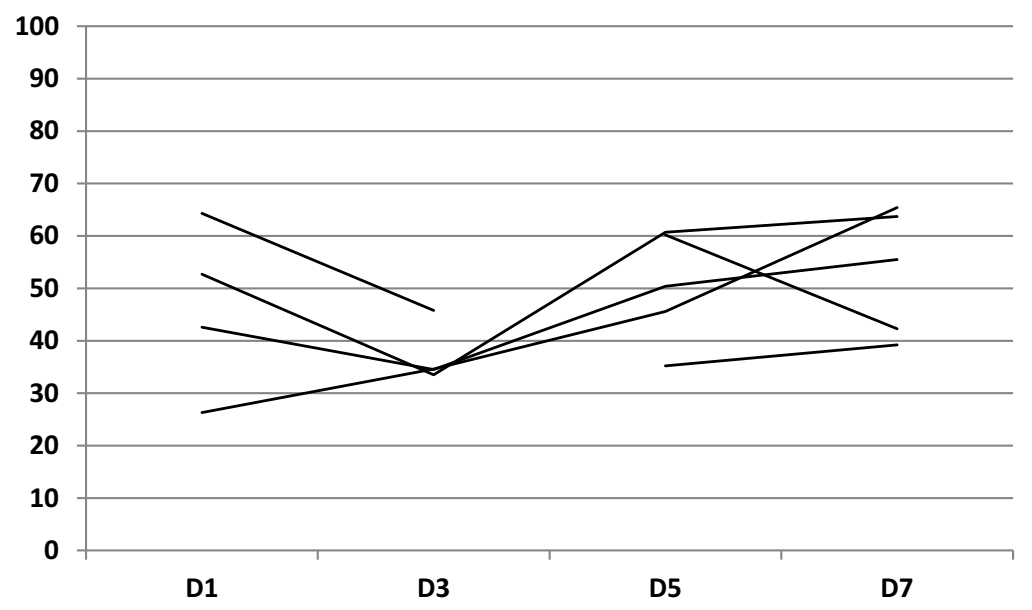

No-IPF group $(n=8)$

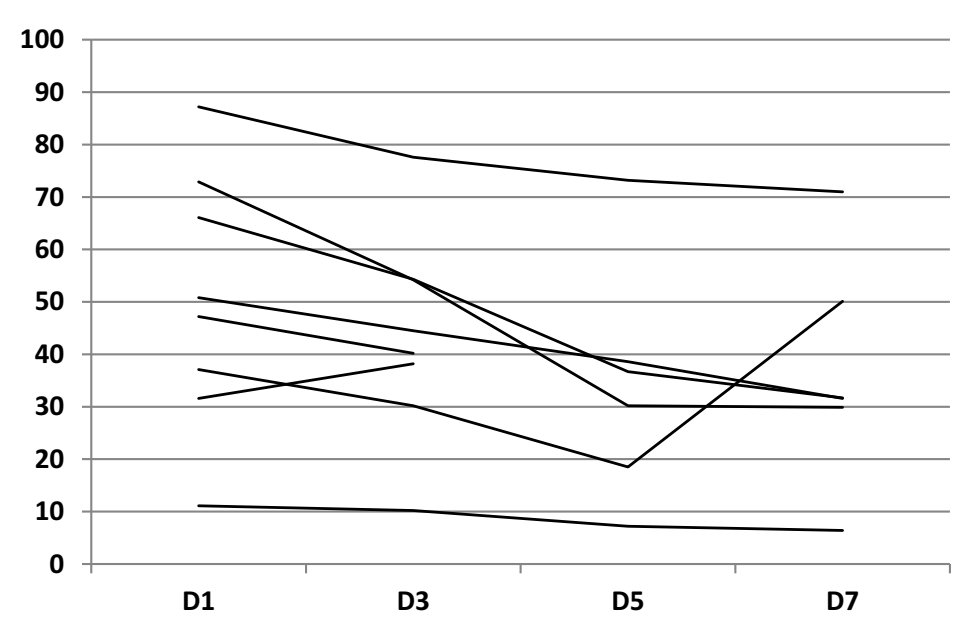

IPF group $(n=11)$

Data are expressed as mean \pm standard error of mean (days 1,3,5, and 7).

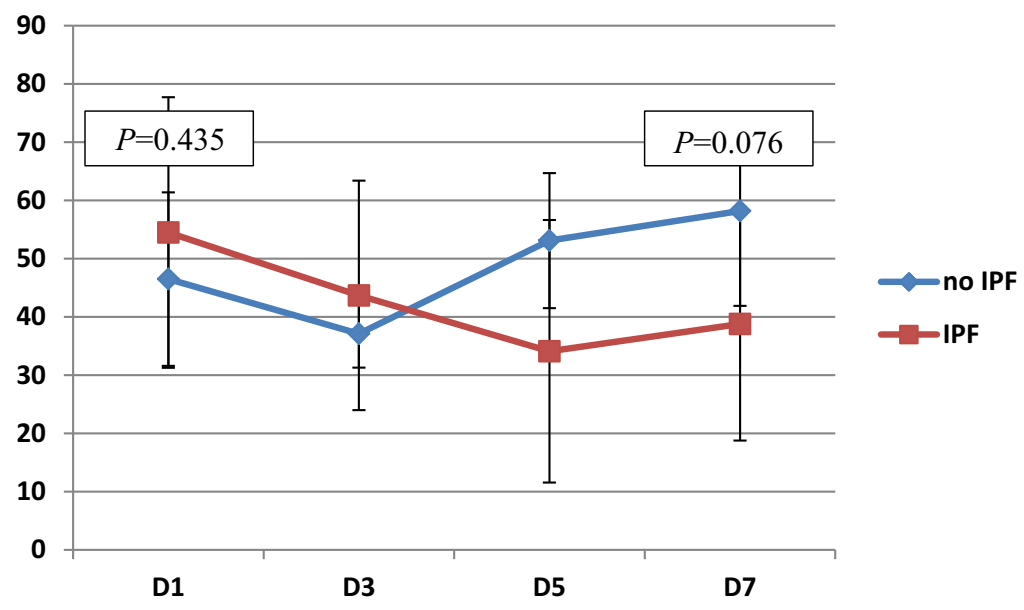


mean \pm standard deviation (SD) and compared using the independent-sample $t$ test. The groups were compared using the nonparametric Wilcoxon test. The qualitative data were expressed as a percentage. The groups were compared using the chi-square test. The test level was 0.05 .

\section{Results}

\section{Patient Characteristics}

The baseline factors are listed in Tables 1 , 2, 3. A total of 19 adult critically ill patients with confirmed H1N1 infection were included in the study between November 2017 and March 2018. Table 1 shows that the patients had a mean age of $49.18 \pm 14.38$ years, and 13 patients $(68.4 \%)$ were male. They were divided into two groups based on the occurrence of secondary fungal infections in the course of the disease: IPF and no IPF. The initial symptoms, body temperature, leukocyte count and neutrophil count were not different between the two groups (Table 2). Also, no difference was observed in the onset to visiting time, aggravation time or ICU time (Table 3). Four patients $(23.5 \%)$ received corticosteroids before admission to hospital as therapy for "severe acute respiratory distress syndrome." All patients received antiviral therapies such as oseltamivir and peramivir. Although the initial antiviral time seemed longer in the IPF group $(10.10 \pm 2.29)$ than in the no-IPF group $(6.86 \pm 2.12)$, the difference was not significant $(P=0.272)$. On admission, the mean APACHE II score was $17.06 \pm 6.81$ and the median SOFA score was $5.35 \pm 3.08$, reflecting a high severity of illness and a high incidence of multiple organ dysfunction syndrome. During hospitalization, the worst oxygenation index of patients was $93.34 \pm 30.57 \mathrm{~mm} \mathrm{Hg}$. The respiratory support methods included extracorporeal membrane oxygenation (ECMO), tracheal intubation, noninvasive ventilation, high-flow nasal cannulae and oxygen therapy.

\section{Patient Prognosis}

The results are shown in Table 4 . In the present study, $15 / 19(78.9 \%)$ of patients, 7 in the IPF group and 8 people in the no-IPF group, were still alive at ICU discharge and hospital discharge. The length of ICU stay and hospital stay was $25.29 \pm 18.04$ days and $25.94 \pm 17.70$ days, respectively. The two groups had no significant difference in the length of ICU stay or hospital stay $(P=0.293$ or 0.200$)$.

\section{IPF Infection}

The study found that $57.9 \%(11 / 19)$ of the critically ill patients with H1N1 infection developed IPF infection during ICU stay (Table 5). The time between diagnosis of influenza and IPF infection ranged from 4 to 12 days, with a mean of 7.3 days and a median of 7 days. On the basis of the modified EORTC/MSG criteria, IPF infection probably occurred in nine patients and was confirmed in two patients. Nine patients were treated with antifungal therapy. All of them were treated with voriconazole.

\section{Immune Function Monitoring}

Table 6 shows that the HLA-DR percentage on days 1 and 7 did not differ significantly between the groups. However, a difference in $\triangle$ HLA-DR (day 7-day 1) was found between the two groups $(P=0.019)$. Also, differences in the NK cell count were observed on day 1 between the two groups. The CD $4+/ \mathrm{CD} 8+$ ratio, percentage of $\mathrm{B}$ cells, percentage of neutrophils and percentage of lymphocytes did not differ significantly between the groups at any of the time points.

\section{Discussion}

The intensive understanding of H1N1 virus, application of vaccines and improvements in treatment options have facilitated the entry into the postpandemic period [16]. Although patients with H1N1 infection in post-pandemic years were less serious than those in the pandemic year, some complications are still common, severe and fatal. A potential complication of influenza is super-infection with fungal species. An increasing number of cases have been reported over time [17-19].

Wauters et al. [15] retrospectively selected all adult patients with confirmed H1N1 virus infection admitted to the ICU of the two tertiary care hospitals from 
Table 1 Demographic and clinical characteristics of the patients included in the study

\begin{tabular}{|c|c|c|c|c|}
\hline & Total $(n=19)$ & No IPF $(n=8)$ & $\operatorname{IPF}(n=11)$ & $P$ \\
\hline Age (year) & $49.2 \pm 14.4$ & $44.4 \pm 12.2$ & $52.5 \pm 15.4$ & 0.268 \\
\hline Sex (male), n (\%) & $13 / 19(68.4 \%)$ & $4 / 8(50 \%)$ & 9/11 (81.8\%) & \\
\hline \multicolumn{5}{|l|}{ Contact history } \\
\hline None & $17 / 19$ & $7 / 8$ & $10 / 11$ & \\
\hline Poultry & $2 / 19$ & $1 / 8$ & $1 / 11$ & \\
\hline \multicolumn{5}{|l|}{ Occupation } \\
\hline Farmer & $6 / 19$ & $2 / 8$ & $4 / 11$ & \\
\hline Unemployed & $7 / 19$ & $4 / 8$ & $3 / 11$ & \\
\hline Other & $6 / 19$ & $2 / 8$ & $4 / 11$ & \\
\hline \multicolumn{5}{|l|}{ Comorbid illness } \\
\hline Healthy & $10 / 19$ & $4 / 8$ & $6 / 11$ & \\
\hline Hypertension & $5 / 19$ & $1 / 8$ & $4 / 11$ & \\
\hline Liver disease & $4 / 19$ & $4 / 8$ & $0 / 11$ & \\
\hline COPD (not taken systemic corticosteroids) & $1 / 19$ & $1 / 8$ & $0 / 11$ & \\
\hline Diabetes mellitus & $2 / 19$ & $0 / 8$ & $2 / 11$ & \\
\hline Coronary heart disease & $4 / 19$ & $1 / 8$ & $3 / 11$ & \\
\hline Atrial fibrillation & $1 / 19$ & $0 / 8$ & $1 / 11$ & \\
\hline Cerebellar hypoplasia & $1 / 19$ & $1 / 8$ & $0 / 11$ & \\
\hline Cerebral infarction & $2 / 19$ & $1 / 8$ & $1 / 11$ & \\
\hline Parkinson's disease & $1 / 19$ & $1 / 8$ & $0 / 11$ & \\
\hline Pregnancy, $n(\%)$ & $3 / 19(15.8 \%)$ & $2 / 8(25 \%)$ & $1 / 11(9.1 \%)$ & \\
\hline Obesity (BMI $\left.\geq 30 \mathrm{~kg} / \mathrm{m}^{2}\right), n(\%)$ & $1 / 19(5.3 \%)$ & $1 / 8(12.5 \%)$ & $0 / 11(0 \%)$ & \\
\hline Worst oxygenation index (mm Hg) & $93.34 \pm 30.57$ & $103.29 \pm 24.03$ & $85.61 \pm 34.14$ & 0.265 \\
\hline \multicolumn{5}{|l|}{ Respiratory support } \\
\hline None, $n(\%)$ & $3 / 19(15.8 \%)$ & $1 / 8(12.5 \%)$ & $2 / 11(18.2 \%)$ & \\
\hline $\mathrm{ECMO}, n(\%)$ & $5 / 19(26.3 \%)$ & $3 / 8(37.5 \%)$ & $2 / 11(18.2 \%)$ & \\
\hline ECMO, days & $9(1-33)$ & $9(8-10)$ & $17(1-33)$ & \\
\hline $\mathrm{MV}, n(\%)$ & $5 / 19(26.3 \%)$ & $2 / 8(25 \%)$ & $3 / 11(27.3 \%)$ & \\
\hline NIV, $n(\%)$ & $5 / 19(26.3 \%)$ & $2 / 8(25 \%)$ & $3 / 11(27.3 \%)$ & \\
\hline Mechanical ventilation, days & $9(0-45)$ & $10(0-17)$ & $8(0-45)$ & \\
\hline HFNC, $n(\%)$ & $1 / 19(5.3 \%)$ & $0 / 8(0 \%)$ & $1 / 11(9.1 \%)$ & \\
\hline Vasopressors, $n(\%)$ & $8 / 19(42.1 \%)$ & $3 / 8(37.5 \%)$ & $5 / 11(45.5 \%)$ & \\
\hline Vasopressor (day) & $0.2(0-40)$ & $0(0-6)$ & $0.5(0-40)$ & \\
\hline Renal replacement therapy, $n(\%)$ & $2 / 19(10.5 \%)$ & $0 / 8(0 \%)$ & $2 / 11(18.2 \%)$ & \\
\hline Renal replacement therapy (day) & $0(0-60)$ & $0(0)$ & $0(0-60)$ & \\
\hline APACHE II & $17.1 \pm 6.8$ & $19.0 \pm 9.0$ & $15.7 \pm 4.89$ & 0.341 \\
\hline SOFA & $5.4 \pm 3.1$ & $4.4 \pm 2.4$ & $6.0 \pm 3.2$ & 0.316 \\
\hline
\end{tabular}

APACHE acute physiology and chronic evaluation score, BMI body mass index, COPD chronic obstructive pulmonary disease, $E C M O$ extracorporeal membrane oxygenation, $H F N C$ high-flow nasal cannula, $I P F$ invasive pulmonary fungus, $M V$ mechanical ventilation days, $N I V$ noninvasive mechanical ventilation, SOFA sequential organ failure assessment

September 2009 to March 2011. These 40 patients had an average APACHE II score of $23 \pm 8$, an average SOFA score of 11 and a high degree of disease risk. Of
40 critically ill patients with confirmed H1N1, 9 (23\%) developed IPA after 3 days of ICU admission. In contrast, the present study focused on recruiting 
Table 2 Initial clinical symptoms, previous treatment and prognosis of the patients

\begin{tabular}{lllll}
\hline & Total $(n=19)$ & No IFI $(n=8)$ & IFI $(n=11)$ & $P$ \\
\hline First symptoms & & & \\
Cough & $19 / 19$ & $8 / 8$ & $11 / 11$ \\
Expectoration & $12 / 19$ & $5 / 8$ & $7 / 11$ \\
$\quad$ Sore throat & $2 / 19$ & $2 / 8$ & $0 / 11$ \\
$\quad$ Wheezing or dyspnea & $2 / 19$ & $1 / 8$ & $1 / 11$ \\
$\quad$ Headache & $1 / 19$ & $0 / 8$ & $1 / 11$ & \\
Initial body temperature $\left({ }^{\circ} \mathrm{C}\right)$ & $39.1 \pm 0.7$ & $39.0 \pm 0.8$ & $39.2 \pm 0.6$ & 0.58 \\
Initial leukocyte $\left(\times 10^{9} / \mathrm{L}\right)$ & $6.9 \pm 3.2$ & $7.5 \pm 3.9$ & $6.3 \pm 2.4$ & 0.466 \\
\hline
\end{tabular}

Table 3 Previous treatment of the patients

\begin{tabular}{|c|c|c|c|c|}
\hline & Total $(n=19)$ & No IFI $(n=8)$ & IFI $(n=11)$ & $P$ \\
\hline Onset to visiting time & $3.7 \pm 5.9$ & $3.1 \pm 2.3$ & $4.0 \pm 7.5$ & 0.777 \\
\hline Onset to aggravation time & $6.6 \pm 5.2$ & $5.0 \pm 2.3$ & $7.7 \pm 6.4$ & 0.306 \\
\hline Onset to ICU time & $9.1 \pm 6.2$ & $6.3 \pm 2.9$ & $11.0 \pm 7.3$ & 0.128 \\
\hline Use of glucocorticoids in the course of disease & $4 / 19$ & $2 / 8$ & $2 / 11$ & \\
\hline \multicolumn{5}{|l|}{ Initial antiviral therapy } \\
\hline Oseltamivir & $15 / 19$ & $5 / 8$ & $10 / 11$ & \\
\hline Peramivir & $4 / 19$ & $3 / 8$ & $1 / 11$ & \\
\hline Time of initial antiviral & $8.8 \pm 5.8$ & $6.9 \pm 2.1$ & $10.1 \pm 2.3$ & 0.272 \\
\hline Time of virus clearance & $10.9 \pm 7.8$ & $12.3 \pm 9.0$ & $9.7 \pm 6.9$ & 0.514 \\
\hline
\end{tabular}

Onset to visiting time: Onset from first influenza symptoms to outpatient visit.

Onset to aggravation time: Patient's symptoms cannot be tolerated.

Time of initial antiviral treatment: Onset of symptoms to start antiviral treatment.

Time of virus clearance: Time for virus to turn negative [The diagnosis of H1N1 virus infection was based on a positive result in a probe-based reverse transcription polymerase chain reaction test for H1N1 from a nasopharyngeal swab or bronchoalveolar lavage (BAL) fluid.]

Table 4 Prognosis of the patients

\begin{tabular}{|c|c|c|c|c|}
\hline & Total $(n=19)$ & no IFI $(n=8)$ & IFI $(n=11)$ & $P$ \\
\hline Alive at ICU discharge, $\mathrm{n}(\%)$ & $15 / 19(78.9 \%)$ & $7 / 8(87.5 \%)$ & $8 / 11(72.7 \%)$ & 0.334 \\
\hline Alive at hospital discharge, $\mathrm{n}(\%)$ & $15 / 19(78.9 \%)$ & $7 / 8(87.5 \%)$ & $8 / 11(72.7 \%)$ & 0.521 \\
\hline Length of ICU stay & $25.3 \pm 18.0$ & $24.6 \pm 11.9$ & $25.8 \pm 22.0$ & 0.293 \\
\hline Length of hospital stay & $26.0 \pm 18.0$ & $26.1 \pm 10.5$ & $25.8 \pm 22.0$ & 0.2 \\
\hline
\end{tabular}

Onset to visiting time: Onset from first influenza symptoms to outpatient visit.

Onset to aggravation time: Patient's symptoms cannot be tolerated.

Time of initial antiviral treatment: Onset of symptoms to start antiviral treatment.

Time of virus clearance: Time for virus to turn negative [The diagnosis of H1N1 virus infection was based on a positive result in a probe-based reverse transcription polymerase chain reaction test for $\mathrm{H} 1 \mathrm{~N} 1$ from a nasopharyngeal swab or bronchoalveolar lavage (BAL) fluid.]

patients from the department within 4 months, indicating that the virus was more homologous and the differences between individuals diagnosed and treated were small. The average APACHE II score was $17.06 \pm 6.81$, and the SOFA score was $5.35 \pm 3.08$. The severity of the disease and organ failure appeared 
Table 5 Overview of all individual cases of IPF infection

\begin{tabular}{|c|c|c|c|c|c|c|c|}
\hline Patient & Fungus & $\begin{array}{l}\text { GM } \\
\text { blood } \\
(\mathrm{pg} / \mathrm{mL})\end{array}$ & $\begin{array}{l}\text { GM } \\
\text { blood }\end{array}$ & $\begin{array}{l}\text { GM } \\
\text { BAL }\end{array}$ & $\begin{array}{l}\text { Day of first indication } \\
\text { of IPF infection after } \\
\text { ICU admission (days) }\end{array}$ & $\begin{array}{l}\text { Diagnosis of } \\
\text { IPF infection }\end{array}$ & Drug \\
\hline 1 & Aspergillus niger, aflatoxin & 93.1 & 0.14 & & 7 & Probable & Voriconazole \\
\hline 2 & $\begin{array}{l}\text { Candida } \\
\text { Albicans }\end{array}$ & 104.8 & 0.32 & & 10 & Probable & Voriconazole \\
\hline 3 & Aspergillus & 24 & 0.98 & & 4 & Probable & Voriconazole \\
\hline 4 & $\begin{array}{l}\text { Aspergillus, } \\
\text { Candida albicans }\end{array}$ & 111.3 & 0.51 & 3.9 & 12 & Probable & Voriconazole \\
\hline 5 & Aspergillus & 97.7 & 0.17 & & 6 & Probable & Voriconazole \\
\hline 6 & $\begin{array}{l}\text { Aspergillus } \\
\text { Fumigatus }\end{array}$ & 188 & 4.74 & 4.89 & 7 & Proven & Voriconazole \\
\hline 7 & $\begin{array}{l}\text { Candida } \\
\text { Albicans }\end{array}$ & 301.2 & 2.31 & & 5 & Proven & Voriconazole \\
\hline 8 & Candida kurou & 17 & 0.06 & & 6 & Probable & None \\
\hline 9 & $\begin{array}{l}\text { Candida } \\
\text { Albicans }\end{array}$ & 31.2 & 0.09 & & 4 & Probable & None \\
\hline 10 & $\begin{array}{l}\text { Candida } \\
\text { Albicans }\end{array}$ & 312.6 & 0.31 & 0.98 & 10 & Probable & Voriconazole \\
\hline 11 & Aspergillus & 9.8 & 0.46 & 0.51 & 10 & Probable & Voriconazole \\
\hline
\end{tabular}

to be less than that reported by Wauter. However, further observations revealed that the patients in the present study had a relatively short period of time from onset to ICU admission, and the statistics included APACHE II scores and SOFA scores within $24 \mathrm{~h}$ of ICU admission. After ICU admission, the disease was still in a developing stage and did not reach the critical peak in $24 \mathrm{~h}$. The lowest oxygenation index was $93.34 \pm 30.57 \mathrm{~mm} \mathrm{Hg}$ in the course of the disease. Also, $88 \%$ of patients opted for mechanical ventilation and $28 \%$ for ECMO. In the study by Wauter, $23.5 \%$ of patients opted for ECMO and $88.2 \%$ for mechanical ventilation. Hence, the patients in the two studies were quite similar in terms of criticality and disease characteristics. In the aforementioned study, the incidence of invasive fungal infection in the lungs was $9 / 40(23 \%)$. In the present study, the incidence was $11 / 19(58.9 \%)$. One possible hypothesis was the evolution of more virulent influenza strains, as exemplified by the pandemic H1N1 strain, causing more severe pneumonia. Compared with previous findings [17], the average viral transposition time of the patients was longer $[(10.88 \pm 7.81)$ days $]$ and the duration of the disease increased in the present study. This result also proved the previous hypothesis. A retrospective study found that the risk of IPF infection was higher when respiratory viruses were in circulation, in particular, influenza A [20]. IPF infections were prone to occur during viral infection and replication process. The time between diagnosis of influenza and IPF infection in 11 patients was a mean of 7.3 days $(\mathrm{SD} \pm 0.7)$. This result was almost consistent with previous findings [21].

The data in the present study suggested that the use of corticosteroids 7 days before ICU admission was an independent risk factor for fungal super-infection. In this study, no-IPF group had prehospitalization rates of $28.6 \%$ and $20 \%$. No significant difference was observed between the two groups, demonstrating no significant relationship between glucocorticoid use and secondary fungal infection before hospital admission. This result was not consistent with previous observations.

Therefore, other mechanisms leading to decreased immune function might exist. Influenza virus affects the production of cytokines, in turn impacting the immune system. H1N1 virus leads to an increased and prolonged production of interleukin-10 (IL-10) in plasma. This, in turn, affects Th2 response and adaptive immunity mediated by $\mathrm{Th} 2$, which is 
Table 6 Immune function monitoring

\begin{tabular}{|c|c|c|c|c|}
\hline & Total $(n=19)$ & No IPF $(n=8)$ & $\operatorname{IPF}(n=11)$ & $P$ \\
\hline HLA-DR day $1(\%)$ & $51.2 \pm 20.1$ & $46.5 \pm 14.9$ & $54.5 \pm 23.2$ & 0.435 \\
\hline HLA-DR day7 (\%) & $47.1 \pm 20.5$ & $58.2 \pm 16.3$ & $38.76 \pm 20.0$ & 0.076 \\
\hline$\triangle$ HLA-DR (day 7-day 1) $(\%)$ & $-0.50 \pm 21.9$ & $14.5 \pm 14.2$ & $-11.7 \pm 20.2$ & 0.019 \\
\hline $\mathrm{CD} 4+/ \mathrm{CD} 8+$ day 1 & $1.5 \pm 0.6$ & $1.3 \pm 0.6$ & $1.7 \pm 0.5$ & 0.293 \\
\hline $\mathrm{CD} 4+/ \mathrm{CD} 8+$ day 7 & $1.7 \pm 1.0$ & $1.3 \pm 1.0$ & $1.9 \pm 1.0$ & 0.757 \\
\hline$\triangle \mathrm{CD} 4+/ \mathrm{CD} 8+($ day $7-$ day 1$)$ & $0.1 \pm 0.8$ & $0.0 \pm 0.6$ & $0.2 \pm 1.0$ & 0.711 \\
\hline NK cell day $1\left(\times 10^{9} / \mathrm{L}\right)$ & $0.1 \pm 0.1$ & $0.1 \pm 0.1$ & $0.1 \pm 0.1$ & 0.950 \\
\hline NK cell day $7\left(\times 10^{9} / \mathrm{L}\right)$ & $0.1 \pm 0.1$ & $0.2 \pm 0.1$ & $0.1 \pm 0.1$ & 0.372 \\
\hline$\triangle \mathrm{NK}$ cell(day $7-$ day 1$)\left(\times 10^{9} / \mathrm{L}\right)$ & $0.0 \pm 0.1$ & $0.1 \pm 0.1$ & $-0.0 \pm 0.1$ & 0.066 \\
\hline B cell day $1\left(\times 10^{9} / \mathrm{L}\right)$ & $0.2 \pm 0.1$ & $0.2 \pm 0.1$ & $0.2 \pm 0.1$ & 0.997 \\
\hline B cell day $7\left(\times 10^{9} / \mathrm{L}\right)$ & $0.2 \pm 0.1$ & $0.2 \pm 0.1$ & $0.2 \pm 0.1$ & 0.776 \\
\hline$\triangle \mathrm{B}$ cell $($ day $7-$ day 1$)\left(\times 10^{9} / \mathrm{L}\right)$ & $0.0 \pm 0.1$ & $0.0 \pm 0.2$ & $0.0 \pm 0.1$ & 0.260 \\
\hline Neutrophils day $1\left(\times 10^{9} / \mathrm{L}\right)$ & $5.5 \pm 3.4$ & $5.4 \pm 4.1$ & $5.6 \pm 3.0$ & 0.414 \\
\hline Neutrophils day $7\left(\times 10^{9} / \mathrm{L}\right)$ & $8.0 \pm 4.1$ & $9.3 \pm 4.4$ & $7.1 \pm 3.9$ & 0.824 \\
\hline$\triangle$ Neutrophils (day $7-$ day 1$)\left(\times 10^{9} / \mathrm{L}\right)$ & $2.6 \pm 3.2$ & $3.8 \pm 4.0$ & $1.5 \pm 2.1$ & 0.135 \\
\hline Lymphocyte day $1\left(\times 10^{9} / \mathrm{L}\right)$ & $0.6 \pm 0.3$ & $0.5 \pm 0.2$ & $0.7 \pm 0.4$ & 0.122 \\
\hline Lymphocyte day $7\left(\times 10^{9} / \mathrm{L}\right)$ & $1.1 \pm 0.5$ & $1.0 \pm 0.5$ & $1.2 \pm 0.5$ & 0.435 \\
\hline$\triangle$ Lymphocyte (day 7-day 1$)\left(\times 10^{9} / \mathrm{L}\right)$ & $0.5 \pm 0.5$ & $0.5 \pm 0.6$ & $0.5 \pm 0.4$ & 0.168 \\
\hline
\end{tabular}

associated with an increased risk of IPF infection [22]. The influenza virus has been reported to impair phagocytosis and alveolar macrophage function, increasing the risk of IPF infection [9]. The severe systemic inflammatory syndrome, which is called compensatory anti-inflammatory response syndrome or immunoparalysis, may occur in patients with severe influenza infection, making them vulnerable to severe super-infections by bacteria and fungi [10].

The immune function indicators of patients were evaluated within 7 days after admission, and the dynamic changes in immune function were observed. In previous studies, a decrease in the peripheral blood lymphocyte count was one of the risk factors for secondary fungal infections [23]. However, this phenomenon was not observed in the present study. Interestingly, the HLA-DR percentage on days 1 and 7 did not differ significantly between the groups. Therefore, the difference in HLA-DR percentage on days 1 and 7 was compared between the two groups in the present study. $\triangle$ HLA-DR (day 7-day 1) was higher in patients with no IPF infection than in those with IPF infection. The decline in HLA-DR indicated impaired immune function secondary to fungal infection in patients with influenza $\mathrm{A} / \mathrm{H} 1 \mathrm{~N} 1$ infection. With constant exposure to fungi, the normal human immune system developed defenses for fungal clearance via alveolar macrophages, neutrophils, monocytes and NK cells [24]. This study showed that a continuous decline in immune function could lead to the development of IPF infections. In previous studies, most patients with aspergillosis associated with influenza did not have classic risk factors or radiographic findings [25]. Therefore, dynamic monitoring of immune function may help in the early detection of IPF infection.

\section{Conclusions}

In summary, IPF infection is a potential complication of severe influenza infection. Progressive pulmonary infection after the initial diagnosis of influenza should raise suspicion of super-infection, including with fungi.

This retrospective study had three limitations. First, the lower percentage of histological examinations under bronchoscopic biopsy might have resulted in missed diagnosis in some patients. Second, only 19 patients were identified and the sample size was 
insufficient to investigate all the features. Finally, how to enhance immune function and its impact on fungal infections need further investigation.

\section{Availability of Data and Materials}

The dataset used and analyzed in the present study is available from the corresponding author on reasonable request.

Acknowledgements The authors are grateful to all doctors and nurses from the Department of Critical Care Medicine, the Affiliated Drum Tower Hospital of Nanjing University Medical School, Nanjing, Jiangsu, China, who participated in the study. They also thank Prof Yayi Hou of Nanjing University Medical School and her team for their help and support.

Authors' Contributions WKY contributed to study design. ZXY, QG and BYZ contributed to data analysis and interpretation and were also involved in the writing of the manuscript. CXC and JT contributed to the writing of the manuscript. All authors read and approved the final manuscript.

Funding The authors received financial support from the National Natural Science Foundation of China (No. 81701953).

\section{Compliance with ethical standards}

Conflict of interest The authors declare no competing interests.

Ethics Approval and Consent to Participate This was a retrospective study. No patient consent was required. The study was conducted in accordance with the amended Declaration of Helsinki.

Consent for Publication Not applicable.

Human and Animal Rights Statement All procedures performed in studies involving human participants were in accordance with the ethical standards of the institutional and/or national research committee and with the 1964 Helsinki Declaration and its later amendments or comparable ethical standards. This article does not contain any studies with animals performed by any of the authors.

Informed Consent Informed consent was obtained from all individual participants included in the study.

Open Access This article is licensed under a Creative Commons Attribution 4.0 International License, which permits use, sharing, adaptation, distribution and reproduction in any medium or format, as long as you give appropriate credit to the original author(s) and the source, provide a link to the Creative Commons licence, and indicate if changes were made. The images or other third party material in this article are included in the article's Creative Commons licence, unless indicated otherwise in a credit line to the material. If material is not included in the article's Creative Commons licence and your intended use is not permitted by statutory regulation or exceeds the permitted use, you will need to obtain permission directly from the copyright holder. To view a copy of this licence, visit http://creativecommons.org/licenses/by/4.0/.

\section{References}

1. Bautista E, Chotpitayasunondh T, Gao Z, Harper SA, Shaw M, Uyeki TM, et al. Clinical aspects of pandemic 2009 influenza A (H1N1) virus infection. New Engl J Med. 2010;362:1708-19.

2. Shrestha SS, Swerdlow DL, Borse RH, Prabhu VS, Finelli L, Atkins CY, et al. Estimating the burden of 2009 pandemic influenza A (H1N1) in the United States (April 2009-April 2010). Clin Infect Dis. 2011;52(Suppl 1):S75-S82.

3. Ambrozaitis A, Radzisauskiene D, Zagminas K, Kupreviciene N, Gravenstein S, Jancoriene L. Influenza A(H1N1)pdm09 and postpandemic influenza in Lithuania. Open Med (Warsaw, Poland). 2016;11:341-53.

4. Kochanek KD, Xu J, Murphy SL, Minino AM, Kung HC. Deaths: final data for 2009. Natl Vital Stat Rep. 2011;60:1-116.

5. Murphy SL, Xu J, Kochanek KD. Deaths: final data for 2010. Natl Vital Stat Rep. 2013;61:1-117.

6. Jain S, Kamimoto L, Bramley AM, Schmitz AM, Benoit SR, Louie J, et al. Hospitalized patients with 2009 H1N1 influenza in the United States, April-June 2009. New Engl J Med. 2009;361:1935-44.

7. Louie JK, Acosta M, Winter K, Jean C, Gavali S, Schechter $\mathrm{R}$, et al. Factors associated with death or hospitalization due to pandemic 2009 influenza A (H1N1) infection in California. JAMA. 2009;302:1896-902.

8. Gill JR, Sheng ZM, Ely SF, Guinee DG, Beasley MB, Suh J, et al. Pulmonary pathologic findings of fatal 2009 pandemic influenza A/H1N1 viral infections. Arch Pathol Lab Med. 2010;134:235-43.

9. Astry CL, Jakab GJ. Influenza virus-induced immune complexes suppress alveolar macrophage phagocytosis. J Virol. 1984;50:287-92.

10. Hartemink KJ, Paul MA, Spijkstra JJ, Girbes AR, Polderman KH. Immunoparalysis as a cause for invasive aspergillosis? Intensive Care Med. 2003;29:2068-71.

11. Alshabani K, Haq A, Miyakawa R, Palla M, Soubani AO. Invasive pulmonary aspergillosis in patients with influenza infection: report of two cases and systematic review of the literature. Expert Rev Respir Med. 2015;9:89-96.

12. Fischer JJ, Walker DH. Invasive pulmonary aspergillosis associated with influenza. JAMA. 1979;241:1493-4.

13. Lewis M, Kallenbach J, Ruff P, Zaltzman M, Abramowitz J, Zwi S. Invasive pulmonary aspergillosis complicating influenza A pneumonia in a previously healthy patient. Chest. 1985;87:691-3.

14. Clancy CJ, Nguyen MH. Acute community-acquired pneumonia due to Aspergillus in presumably immunocompetent hosts: clues for recognition of a rare but fatal disease. Chest. 1998;114:629-34. 
15. Wauters J, Baar I, Meersseman P, Meersseman W, Dams K, De Paep R, et al. Invasive pulmonary aspergillosis is a frequent complication of critically ill $\mathrm{H} 1 \mathrm{~N} 1$ patients: a retrospective study. Intensive Care Med. 2012;38:1761-8.

16. Rao S, Torok MR, Bagdure D, Cunningham MA, Williams JT, Curtis DJ, et al. A comparison of H1N1 influenza among pediatric inpatients in the pandemic and post pandemic era. Journal Clin Virol. 2015;71:44-50.

17. Shah MM, Hsiao EI, Kirsch CM, Gohil A, Narasimhan S, Stevens DA. Invasive pulmonary aspergillosis and influenza co-infection in immunocompetent hosts: case reports and review of the literature. Diagn Microbiol Infect Dis. 2018;91(2):147-52.

18. Su PA, Yu WL. Failure of extracorporeal membrane oxygenation to rescue acute respiratory distress syndrome caused by dual infection of influenza A (H1N1) and invasive pulmonary aspergillosis. J Formosan Med Assoc. 2017; 116:563-4.

19. Igarashi A, Tokairin Y, Hirono O, Kato T, Kubota I. Two cases of mixed infection following 2009 H1N1 influenza pneumonia. Nihon Kokyuki Gakkai zasshi. 2011;49:226-31.

20. Garcia-Vidal C, Royo-Cebrecos C, Peghin M, Moreno A, Ruiz-Camps I, Cervera C, et al. Environmental variables associated with an increased risk of invasive aspergillosis. Clin Microbiol Infect. 2014;20:O939-O945945.
21. Hoyo-Ulloa I, Cobos-Trigueros N, Puig-de la Bellacasa J, Martinez-Martinez JA. Influenza A (H1N1) complicated by invasive aspergillosis in non-severely immunocompromised patients. Enferm Infecc Microbiol Clin. 2012;30:583-4.

22. Roilides E, Sein T, Roden M, Schaufele RL, Walsh TJ. Elevated serum concentrations of interleukin-10 in nonneutropenic patients with invasive aspergillosis. J Infect Dis. 2001;183:518-20.

23. Crum-Cianflone NF. Invasive aspergillosis associated with severe influenza infections. Open forum Infect Dis. 2016;3:ofw171.

24. Morrison BE, Park SJ, Mooney JM, Mehrad B. Chemokinemediated recruitment of NK cells is a critical host defense mechanism in invasive aspergillosis. J Clin Investig. 2003;112:1862-70.

25. Park SY, Lim C, Lee SO, Choi SH, Kim YS, Woo JH, et al. Computed tomography findings in invasive pulmonary aspergillosis in non-neutropenic transplant recipients and neutropenic patients, and their prognostic value. J Infect. 2011;63:447-56.

Publisher's Note Springer Nature remains neutral with regard to jurisdictional claims in published maps and institutional affiliations. 